ler. Bedømt ud fra de portrætter jeg har set, synes der at være noget om antagelsen [...] Til gengæld ved jeg fra selvsyn, at alle svenske digtere [...] ligner overlæger eller, for de yngres vedkommende, første reservelæger. I sig selv er det en rørende tanke: i den ene ende af verden digtere der vil tilintetgøre, i den anden digtere der vil helbrede. To slags poesi hvis læsere er hhv. fjender og patienter« (p. 222f). Der er selvkritiske og -ironiske tekster, hvor Frank f.eks. taler om, at "jeg forsøger at imitere den let skødesløse, selvironiske, uforpligtende stil, man normalt forbinder et essay med, som betegnede essayet blot en slags ophøjet fritidsstil: essayet som en herreværelsesgenre, en kultiveret og underholdende genre fuld af antagelser, ingen gider efterprøve« (p. 263). Og der optræder absurdistiske tragikomiske beretninger med brod mod Franks eget værk, hvor man hører: "Endnu en aften midt i dette snevejr af papirlapper, som skal blive til en bog « (p. 80). Eller: »Redaktøren råbte op: det nye manuskript var jo langt hen genbrug af gamle tekster, som allerede var blevet udgivet. Og i øvrigt havde solgt meget dårligt! [...] Hvorfor ikke bare opgive det, hvorfor ikke bare gå hjem og bage et brød i stedet for [...]«(p. 273). Det gjorde Frank heldigvis ikke. For ganske vist kan mangt og meget indvendes mod Franks bogprojekt, såsom at der er tale om en rodet og kaotisk bog med megen genbrug. Til gengæld er det uden for enhver diskussion og skammeligt overset, at vi har at gøre med den mest udfordrende, banebrydende og originale samling poetologiske og æstetikteoretiske essays, som man har set i dansk litteratur i flere årtier.

\section{Unni Langås}

\section{Et viktig erindrings- politisk arbeid}

Anne Birgitte Richard: Køn og kultur. 1930ernes og 1940ernes kamp om køn, kultur og modernitet loest gennem kvindernes tekster. Kbh. 2005 (Museum Tusculanum).

Anne Birgitte Richard har med sin bok Køn og kultur levert en stor litteraturhistorisk studie til belysning av dansk kultur i mellomkrigstiden. Studien er et omfangsrikt erindringspolitisk arbeid som i detalj og bredde belyser kvinnelige forfatteres tekster og deres samspill med de kjønnsrelaterte temaene i tiden. Komposisjonen i boka er firedelt og går på tvers av de tradisjonelle litteraturhistoriske inndelinger og kvalitetshierarkier, idet Richard isteden ønsker å innkretse noen overgripende figurer som hun kaller Kosmos, Tiden, Naturen og Barnet. I den første delen omtaler hun forfatterne Johanne Buchardt, Hulda Lütken, Bodil Bech og Tove Meyer. I den andre omtales Aase Hansen, Ellen Raae, Karen Blixen, i tillegg til de nye massemedier beregnet på kvinner, samt de skolepolitiske, seksualpolitiske og ideologiske debatter. I den tredje følger gjennomganger av forfatterskapene til Ellen Duurloo, Caja Rude og Jo Jacobsen, samt en diskusjon av de høyrepopulistiske, sosialdemokratiske og kommunistiske strømninger og deres innlegg i den kjønnspolitiske debatten. Den siste delen omhandler forfatterne Sonja Hauberg og Tove Ditlevsen. 
Studiens materiale er svært grundig behandlet og etterlater ingen tvil om at forfatteren er en meget kompetent og sensitiv nærleser og en forsker med utpreget sans for syntetiserende grep. Metoden kan sies å være en avansert parafrase, idet Richard gjenforteller og fortolker samtidig som hun åpner tekstene opp for lesere som presumptivt ikke kjenner dem. Resultatet er i god litteraturhistorisk ånd en blanding av formidling, fortolkning og nyskapende forskning. Formidlende fordi forfatteren fører leseren med vennlig, men bestemt hånd inn i forfatterskaper som ikke tilhører allmennkunnskapen. Fortolkende fordi hun gir autoritative analyser og innordner dem i de overordnede problemstillinger og intensjoner. Nyskapende forskning fordi hun løfter fram tekster og plasserer dem i sammenhenger som gir dem ny betydning og relevans.

Sjangeren er ikke bare litteraturhistorie, men kvinnelitteraturhistorie, og dét er i dag ikke lenger uproblematisk (om det noensinne har vært det). Spørsmålet er selvsagt hvor relevant og aktuelt det er å avgrense materialet til kvinnenes tekster når det er kampen om kjønnet, kulturen og moderniteten som står på spill. Ganske sikkert ville en dialogisk lesning av både menns og kvinners tekster ha utvidet, beriket og kanskje endog problematisert det bildet av kjønnskampen i tiden som avhandlingen har som sitt siktemål å avdekke. Dessuten kan en avgrensning av materialet til kvinnelige forfattere bidra til å opprettholde et inntrykk av at kvinner skriver som de gjør fordi de er kvinner. Dette har som uintendert bieffekt at den kjønnsdikotomi og det kjønnshie- rarki som avhandlingen ønsker å bryte ned, isteden blir opprettholdt.

Avhandlingen er empirisk anlagt, og selv de mange teorier og teoretikere som blir trukket inn, kommer til å framstå som deler av det empiriske materialet og ikke som forutsetning og begrunnelse for utvalget av tekster og måten å lese på. Resultatet av dette blir at det for leseren er vanskelig å oppdage hvor forfatteren selv befinner seg, og det gjør det ikke enklere at også tesene og konklusjonene er nokså allmenne i sine utsagn. Totalinntrykket blir dermed at den store tekstmassen som er empirien, riktignok blir behandlet både innsiktfullt og omsorgsfullt, men at de litteraturhistoriske og kjønnspolitiske resultater står fram nokså uprofilert. Køn og kultur er en rik tekst og et lærerikt forskningsarbeid, men den tenderer også til å la de klare linjer og markante resultater drukne i tekstomtaler og detaljer.

Jeg skal i denne omtalen peke på noen enkelte problemer som har særlig relevans for kjønnsspørsmålet. ${ }^{1}$ Undertittelen på boka er »1930ernes og 1940ernes kamp om køn, kultur og modernitet læst gennem kvindernes tekster«. Denne tittelen er ikke helt presis, for det som menes, er kvinnenes skjønnlitterære tekster. I tillegg leses nemlig 1930- og 40-tallets kamp om kjønn, kultur og modernitet, og kvinnenes skjønnlitterære tekster, i stor

1. Omtalen bygger på min opposisjon ved disputasen ved Roskilde Universitetscenter, den 27. mai 2005. Opposisjonen er under publisering i Edda, nr. 1, 2006, som også vil inneholde Anker Gemzøes opposisjon samt doktorandens svar. 
grad gjennom mennenes teoretiske tekster. Dette skaper en ironi i prosjektet som er verdt å peke på. Inspirert av den psykoanalytiske dekonstruksjon, kan vi kanskje si at det i studien er både en bevisst og en ubevisst intensjon på gang, og at de motarbeider hverandre. Den bevisste intensjonen er å forandre historieskrivingen med et erindringspolitisk arbeid for at vi skal huske de kvinnelige forfatterne, og for at de skal få den betydningen som de rettmessig skal ha som fortolkere av sin tid. Samtidig er det en ubevisst prosess som undergraver dette prosjekt siden menns teoretiske tekster faktisk fortrenger kvinnenes teoretiske tekster og dessuten legger premisser for lesningen av kvinnenes tekster.

Ett eksempel på dette er den utstrakte henvisningen til Leo Bersani, som Richard støtter seg til selv om hans dekonstruktive tekstsyn ikke matcher hennes hermeneutikk. Men i tillegg avviser hun flere kvinnelige teoretikere fordi de ikke når opp til ham, verken teoretisk eller emansipatorisk. I diskusjonen av de poststrukturalistiske kjønnsteoriene trekker Richard inn Dorte Marie Søndergaards avhandling Tegnet på kroppen og hennes inspirasjonskilde, Judith Butler, for å framheve Leo Bersani som en mer radikal tenker med et bedre emansipatorisk sikte enn dem. Hvorfor Bersani, som ifølge Richard ikke diskuterer kjønnsforskjellen i det hele tatt, skulle være mer emansipatorisk i sin forskning og i sin kulturpolitiske funksjon enn Søndergaard og Butler, er for meg ubegripelig.

Et sentralt tema i Kon og kultur er kvinnenes bidrag til forståelse av moderniteten. I kapitlet »Fremmed, fri og moderne. Ansatser til begrebsafklaring (p. 17) framheves disse tre fenomenene - fremmedheten, friheten og moderniteten - som særlig viktige for kvinnenes liv i perioden. Dette kommer til syne $\mathrm{i}$ deres tekster $\mathrm{i}$ form av "en tøven og en vegring«, skriver Richard, som en tvil på hvordan de skal forholde seg til og gå inn i sin tid. Det er likevel ikke kvinnenes modernitetsfortellinger Richard tar utgangspunkt i, men mannlige teoretikeres ulike modernitetsdiskusjoner og -konstruksjoner. Det begynner med Hans Jørgen Schanz, som trekker modernitetens utviklingshistorie tilbake til antikken. Deretter vises det til Peter Bergers modernitetskritikk. Så til Nietzsche, Frankfurterskolen og Habermas, før det konkluderes med at modernitetsbegrepet er mangetydig og vanskelig å håndtere, men at det skal leses ut av tekstene.

Jeg savner en innarbeiding av kjønnsspesifikke analyser av det moderne, for eksempel Rita Felskis The Gender of Modernity (1995). Den handler riktignok om perioden rundt forrige århundreskifte, men den er illustrerende fordi den så tydelig og bevisst diskuterer det moderne $\mathrm{i}$ forhold til kjønnet, og viser hvordan både kjønn og modernitet er forestillinger som blir produsert i forhandlinger som både kvinner og menn - selvsagt deltar i. Når Richards prosjekt er å diskutere modernitet i relasjon til litteratur og kvinner, så kunne man forvente at hun ville trekke inn bidrag med et eksplisitt kjønnsperspektiv, som er mer direkte relevant enn Schanz, Berger og Habermas.

I innledningsavsnittet "Sammenhæng og moderne tider« (p. 12) utpekes 
modernismen til den estetiske retning som tradisjonelt er blitt knyttet til det moderne. Også her synes jeg at Richard har en normativ holdning som ikke helt kler prosjektet. Modernitet, modernisme og det moderne er tre begreper som innledningsvis blir positivt omtalt. Likesom kvinnene "tøver og vegrer seg“ overfor det moderne, er de også sent ute med å skrive modernistisk, og det framstilles som en klar svakhet. Dette forklarer Richard med deres manglende litterære skolering og det at de derfor ikke hadde like lett for å tilegne seg et vanskelig formspråk som mennene. Dette er paradoksalt, ifølge Richard, fordi deres følelse av fremmedhet og splittelse nettopp burde egne seg for en modernistisk estetikk. Først med 50tallets og 60-tallets modernister får kvinnene et bevisst forhold til språket, hevdes det (p. 17).

Jeg synes det er problematisk å si at kvinnene ikke har et bevisst forhold til språket selv om de ikke skriver modernistisk. Det viser seg jo faktisk at det ikke er noe problem for dem å formulere modernitetens temaer og problemstillinger innenfor andre retninger enn modernismen, eller for litteraturforskeren å analysere dem fram. Richard skriver på side 17: "For de spørgsmål, som kvinderne stiller til de nye fortolkningsmåder, det moderne samfund og de tabte verdier, er overvejende implicitte spørgsmål, der primcert kan loeses ud af teksternes forgaves harmoniseringsforsøg:" Her virker det nærmest som om Richard har fasiten på hva de moderne spørsmålene er, og at de kvinnelige forfatterne har tematisert dem temmelig ubevisst.

Jeg tillater meg å betvile det Richard skriver om den kvinnelige uskolerthet og ubevissthet. Selv har jeg arbeidet litt med forfatterskapet til Bodil Bech, som ga ut fem diktsamlinger i perioden 1934 til 1941. Hun er tydelig inspirert av den poeten som med stor rett kan sies å ha grunnlagt den modernistiske lyrikken i Norden, nemlig Edith Södergran. Det er også et forfatterskap som ved nærmere ettersyn forholder seg til et stort europeisk intertekstuelt felt, først og fremst et mytologisk og religiøst felt. Denne interessen har hun felles med de fremste modernister i nordisk og europeisk lyrikk, for eksempel Erik Lindegren og T.S. Eliot. Richard skriver også at de nyeste lyriske bevegelser klinger med i Bechs diktning, og nevner ekspresjonisme, surrealisme og symbolisme, og dessuten at hun var knyttet til tidsskriftet linien og var gift med medstifteren av Klingen. Bodil Bech var også vidt bereist, osv. Alt dette harmonerer med andre ord dårlig med det generelle bildet som gis av de kvinnelige forfatternes manglende kunnskaper.

Når vi er inne på det estetiske, så vil jeg også nevne melodramaet, som Richard identifiserer som en viktig form hos flere forfattere. Hun skriver om det i forbindelse med Hulda Lütken, Caja Rude, Jo Jacobsen, Bodil Bech og Aase Hansen. Melodramaet er en sjanger som er blitt fortolket som et moderne svar på tap av stabile etiske $\mathrm{og}$ religiøse verdier, og som gjennomgående har hatt en lavstatusposisjon i det estetiske hierarkiet. Her refererer hun ganske kort til Peter Brooks og hans klassiske The Melodramatic Imagination (1985), og det er selvsagt relevant. Men Brooks har ikke noe spesielt kjønnsperspektiv i sin studie, og i forlengelsen av ham har flere 
kvinner gitt feministiske bidrag til tolkningen av melodramaet. Jeg kan nevne E. Ann Kaplans Motherhood and Representation: The Mother in Popular Culture and Melodrama, Christine Gledhills Home is where the Heart is. Studies in Melodrama and the Woman's Film og den før nevnte Rita Felskis bok The Gender of Modernity. Det fins også en ganske ny studie av melodramaet i nordisk litteratur, nemlig Maria Karlssons bok Känslans röst om Selma Lagerlöfs romaner fra 2002.

Det er selvsagt ikke mulig å ta hensyn til alle relevante bidrag i en så omfattende og litteraturhistorisk orientert avhandling som Anne Birgitte Richard har skrevet, men ofte synes jeg at de detaljerte og lange tekstparafrasene ikke får tilstrekkelig kontekstualisering. Hvorfor skriver kvinnene melodrama og ikke modernisme? Hva betyr det for deres status i den litterære offentligheten $\mathrm{og}$ for verdien av deres kunst? Når tekstene ikke sjelden får en teoretisk belysning som mangler det spesifikt kjønnede perspektiv, så framstår det desto mer som et savn. Med impulser fra disse feministiske lesningene av det litterære og filmiske melodrama, tror jeg at boka på en tydeligere måte kunne ha fått fram hvordan og med hvilken effekt kjønnet knytter seg til og produserer estetiske normer og hierarkier.
Jon Helt Haarder

\section{Mellemkød, blandt andet}

Per Stounbjerg: Uro og urenhed. Studier $i$ Strindbergs selvbiografiske prosa, Århus 2005 (Aarhus Universitetsforlag).

Har man været væk fra Strindberg lidt, glemmer man let, hvor ekstrem han er som selvbiograf. Kæfter op om eksens monsteragtige mangel på moral og abeagtigt intellektuelle underlegenhed, og siger så: »Ja, jeg holder mig for god til overhovedet at nævne, at hendes mellemkød revnede efter den første fødsel, og værre blev det kun efter de næste tre, adr mand!« Nu har jeg pendlet lidt rundt på nettet, der egner sig fortrinligt til at hævne sig på ekser ved hjælp af offentliggjorte slibrigheder, og meget interessant kød har jeg set, men ikke lige bristet mellemkød. August, du styrer stadig.

Per Stounbjergs disputats om August Strindbergs selvbiografiske prosaforfatterskab var ved at få samme status som Per Højholts Auricula. Man vidste den var på vej, men vejen var lang. I et selvbiografisk forord oplyser Stounbjerg, at afhandlingen i det væsentlige var færdig helt tilbage i 1993, men så gik der lige ti år med forskellige ledelsesposter. Offentliggjorte artikler har undervejs antydet, at den var værd at vente på - og her sidder anmelderen så med „Uro og urenhed. Studier i Strindbergs selvbiografiske prosa", der blev forsvaret den 27. maj 2005. 